\title{
RULES
}

OF TIE

\section{Board of Live Stock Commissioners,}

OF TIE

\section{STATE OF ILLINOIS,}

FOR THE GOVERNIIENT OF TIIE

STATE, ANI) ASSISTANT STATE VETERINARIANS.

WITII TIIE

STATUTE OF 1887,

FOR TIE

Sngppression of Contagious Diseases among Domestic Animals,

And other Information connected with the work of the Board.

RULES ADOPTED JUNE 28, 1887.

SPRINGFIELD, ILL.:

Phicles Brotmens, Printers, $188 \%$. 



\section{RULES}

OF THE

Tllinois.

\section{Board of Live Stock Commissioners,}

OF THE

\section{STATE OF ILLINOIS,}

FOR THE GOVERNMENT OF THE

STATE, AND ASSISTANT STATE VETERINARIANS.

WITH THE

STATUTTE OF 1887 ,

FOR THE

Suppression of Contagious Diseases among Domestic Animals,

And other Information connected with the work of the Board.

RULES ADOPTED JUNE 28, 1887. 


\section{RULES.}

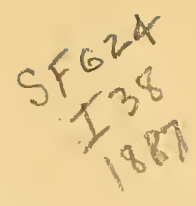

1. When a supposed case of contagious pleuro-pneumonia, or lung plague in cattle is reported to the State, or an Assistant State Veterinarian, he shall at once notify the Secretary of this Board of such report, and immediately thereafter make a thorough examination of the diseased animal or animals, and, if he has good reason to believe that the case under consideration is contagious pleuro-pnenmonia or lung plague, he shall at once quarantine the animal or animals diseased, and the premises, and all exposed animals, and promptly report his action to the Secretary of this Board.

2. When a supposed ease of Glanders in horses, mules or asses is reported to the State Veterinarian, or an Assistant State Veterinarian, he shall at once notify the Secretary of this Board, and shall also mail to the owner or informant the list of questions prescribed by this Board, with a request to answer the same. Upon receipt of answers to these questions, if he believes the animals are affected with glanders, he shall at once visit the premises where such animals are and thoroughly examine the same, and, if upon examination he is satisfied that the disease is glanders, he shall quarantine the animal or animals and premises, and also quarantine all animals or premises that have been exposed to such disease, and promptly notify the Secretary of this Board of his action. Should the answers to the questions above referred to convince him that the disease is not glanders, he shall at once report that conclusion to the Secretary, accompanying the same with all the correspondence relative to the case, and also notify the owner or informant of his opinion.

3. The State Veterinarian and Assistant State Veterinarians will inspect the horses of all circus troupes (not already inspected), bands of Gypsies, and herds of horses brought into this State by traders, and if the same are found to be infected with glanders, quarantine them and all animals exposed, and notify the sheriff and other proper officers of the county, and immediately report his action to the Secretary of this Board.

4. All quarantines established by the State or any of the Assis tant State Veterinarians shall continue in force until removed by 
order of the Board. Parties whose animals are quarantined under the provisions of law may have the same released from quarantine by making satisfactory proof to the Board that the canse for which such quarantine was originally declared no longer exists; Provided that no quarantine as to animals shall be removed in less time than ninety days after the last exposure.

5. The State Veterinarian and the Assistant State Veterinarians in reporting under Rules Nos. 1, 2 and 3, shall give the name and post office address of the owner of animals inspected, location of such animals, date of inspection, complete description of animals diseased and of animals exposed, a description of the exposure to which they have been subjected, the eondition of the diseased animals, the value of such animals in their condition $a^{\text {t }}$ the time of inspection, their value were they free from glanders, the name and address of the nearest constable, and the time employed in sueh investigation. The report must be accompanied by an exact duplicate of the quarantine notice served with return made thereon of the manner of service, and all correspondence with all persons relative to the case. Said report must be addressed to the "Board of Live Stock Commissioners of the State of Illinois," and directed to the Seeretary at Springfield, Ill.

6. Whenever it shall come to the knowledge of an Assistant State Veterinarian that animals have been brought into his loeality from a State or eounty known or believed to be infected, against which the Governor of this State has proclaimed, he shall immediately notify the Secretary of this Board of the facts so far as he knows them, covering the following points, viz: loeality from whence such animals came; name and post office address of owner or person in charge; if shipped by railroad or boat, giving name or names of same, time of arrival; number, age, sex and breed of animals so far as it is practicable to ascertain.

7. Assistant State Veterinarians shall be entitled to receive for their services the sum of one dollar per hour for parts of a day less than eight hours, but in no ease shall they receive more than eight dollars per day for their services while engaged in the public service; neither shall they be permitted to make any charge, nor receive any compensation from a private individual during the time they are actually employed and paid by the State.

8. Any person desiring to ship any animal or animals from this State to another State, the authorities of which require health certificates to aecompany such animal or.animals, may call upon the State Veterinarian, or any Assistant State Veterinarian and request him to inspect such animal or animals. It shall thereupon be the duty of 
the Veterinarian applied to, to at once make such inspection, and, if he finds the animal or animals to be healthy, and to come from a locality wherein there does not, or has not for four months preceding, existed any case of contagious disease among the kind of animals in question, he shall give to the owner of such animal or animals a certificate of health, specifying the number, sex and breed of said animal or animals. For such services the Veterinarian shall be entitled to receive from the owner the same compensation as herein allowed him by the State, together with his necessary expenses in going from and to his regular place of business or abode. In no rase shall the State be liable for the cost of such services; neither shall the Veterinarian receive from any private person for such service a compensation greater than that herein anthorized. Any violation of this provision shall be considered sufficient ground for dismissal from the service of the State. At the end of each month Veterinarians making such inspections are required to make a tabulated report of the same to the Secretary of this Board.

RULES FOR DISINFECTION.

The following rules of disinfection are recommended by Dr. Casewell, State Veterinarian:

1. Have all loose litter, hay and rubbish removed and burned.

2. Have all manure removed to land where cattle have no access.

3. Have all feed troughs, hay racks, and all wood work thoroughly cleaned by washing with hot water in which two ounces of carbolic acid to each gallon of water are dissolved.

4. Thoroughly whitewash the whole of the interior of the building with a whitewash containing one pound of chloride of lime to each four gallons of water. Enough freshly burned quick lime should be added to make the wash show where applied. Especially should this be applied to the sides and front of the stalls, feed troughs and hay racks, (inside and out).

5. All rotten wood work to be removed and burned, and replaced with new.

6. All buckets, forks, shovels, brooms and other objects, used about the stable to be washed and covered with the same solution.

7. All drains to be thoroughly cleaned and disinfected with the solution of chloride of lime, one pound to four gallons of water.

8. In cases of glanders, all harness, poles and shafts of wagons, neck-yokes and pole-straps should be thoroughly washed with hot 
water and soap, and afterwards oiled with carbolized oil, one part of carbolic acid to ten of oil. Before applying the oil, harness should be hung up in the open air for one week.

John M. Pearson,

H. McChesner,

E. S. WILson,

Adopted June 28, 1887.

Bourd of Live Stock Commissioners

C. P. Johnson, Sec'y. of the State of Illinois.

Assistant State Veterinarians.

The following Veterinary Surgeous have been appointed by Dr. John Casewell, State Veterinarian, in pursuance of Sec. 3, of the Act of 188\%, for the suppression of contagious diseases among domestic animals, by and with the advice of the Board, Assistant State Veterinarians:

Joseph Hughes, ....... 125, Twenty-fifth St., Chicago, Ill. A. H. Baker,.........145 Michigan Avenue, Chicago, Ill. *John P. Bond, .......1250 Wabash Avenue, Chicago, Ill.

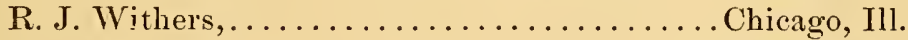

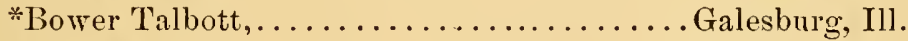
IV. L. Williams, . . . . . . . . . . . Bloomington, Ill.

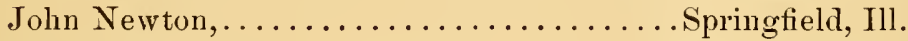

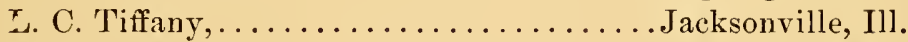
Walter Tomlinson, .................... Alexis, Ill.

C. A. Pierce,$\ldots \ldots \ldots \ldots \ldots \ldots \ldots \ldots \ldots \ldots$ Elgin, Ill.

A. Maguire,$\ldots \ldots \ldots \ldots \ldots \ldots \ldots \ldots \ldots \ldots$ Joliet, Ill.

G. W. Stimpson, ......................

B. F. Swingley, ................... Freeport, Ill.

B. A. Pierce,$\ldots \ldots \ldots \ldots \ldots \ldots \ldots \ldots$ Aurora, Ill.

J. Stallman, ..........................

IV. J. Elliott, .................... Peoria, Ill.

J. F. Reid, . . . . . . . . . . . . . . Decatur, Ill.

C. II. Paxton, . . . . . . . . . . . . . . Kansas, Ill.

IV. A. Baker, .................. Champaign, Ill.

*A. D. Melvin, . ........................ Sterling, Ill.

E. J. Sterner,$\ldots \ldots \ldots \ldots \ldots \ldots \ldots \ldots \ldots$ Bushnell, Ill.

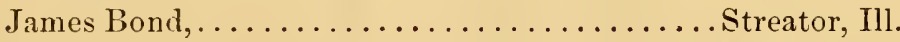

Wm. Graham,........................

P. C. Dodge..$\ldots \ldots \ldots \ldots \ldots \ldots \ldots \ldots$ Rochelle, Ill.

W. H. McKinney, .................... Geneseo, Ill. 
Thos. Hope,................. Waukegan, III.

B. B. Page,$\ldots \ldots \ldots \ldots \ldots \ldots \ldots \ldots$. . . . . . . . . .

J. C. Booker,.................... Jerseyville, Ill.

Jno. C. Stewart,................... Danville, Ill.

I. J. Miles, . . . . . . . . . . . . . Charleston, Ill.

*At present employed by the Department of Agriculture, U. S,, in the Cook County Pleuro-pneumonia outbreak.

The following United States Inspectors have been commissioned as Assistant State Veterinarians, for the purpose of enabling them to assist in the work of extirpating contagious pleuro-pnemmonia from this State.

H. S. Devoe, N. H. Paaren, T. J. Herr, Geo. C. Faville and Jas. Anderson.

The following have been commissioned to inspect cattle for shipment: Isaac Lathrop, Terre Haute, Ill. and M. B. Bristol, Cambridge, Ill.

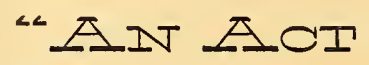

To revise the law in relation to the suppression and prevention of the spread of contagious and infections diseases among domestic animals," approved June 27,1885 , in force July 1, 1885; as amended by an Act approved and in force April 20, 1887, and an Act approved June 15, 1887, in force July 1, 1887.

"Section 1. Be it enacted by the People of the State of Illinois, represented in the General Assembly, That the Governor shall, with the advice and consent of the Senate, appoint three practical stock breeders, not more than two of whom shall be members of the same political party, who shall constitute a Board of Live Stock Commissioners, who shall hold their office in the order in which they are named, the first for one year, the second for two years, and the third for three years; and their successors in office shall be appointed for three years each. Before entering on the duties of their office they shall take and subseribe to an oath of office for the faithful performance of their duties as such Commissioners, and shall file the same with the Governor.

"Section 2. It shall be the duty of said Board of Commissioners to cause to be investigated any and all cases or alleged cases coming to their knowledge, of contagious or infectious diseases among domestic animals, and to use all proper means to prevent the spread of such diseases, and to provide for the extirpation thereof; and in the 
event of reasonable ground for belief that any such contagious or infectious disease has broken ont in this State, it shall be the duty of the person owning or having in charge any animal or animals infected with disease, or any other person having knowledge or reason to suspect the existence of such disease, to immediately notify said Board of Commissioners, or some member thereof, by communication to said Board of the existence of such disease, and thereupon it shall be the duty of said Board, or some member thereof, or authorized agent of the Board, immediately to cause proper examination thereof to be made, and if said disease shall be found to be a dangerously contagious or dangerously infectious malady, said Board or any member thereof, or the State Veterinarian or any Assistant Veterinarian, shall order said diseased animals, and such as have been exposed to contagion, and the premises in which they are, to be strictly quarantined for such time as the Board, or any member thereof, or such Veterinarian may deem necessary, in charge of such person as the Board, or any member therenf or such Veterinarian shall designate, and they shall have power to order any premises and farms where the disease exists, or has recently existed, as well as exposed premises and farms to be put in quarantine, so that no domestic animal which has been, or is so diseased, or has been exposed to such contagious or infectious disease, be removed from the places so quaratined nor allow any healthy animal to be brought therein, except under such rule or regulation as the said Board may prescribe; and said Board shall prescribe such regulations as they may deem necessary to prevelt such disease from being communicated in any way from the places quarantined. In all such cases of contagious and infectious diseases, the said Board or, in case the number of animals shall not exceed five, any member thereof, shall have power to order the slaughter of all such diseased and exposed animals. The said Board shall have power to cause to be destroyed all barns, stables, premises, fixtures, furniture and personal property infected with any such contagious or infectious disease, so far as in their judgment may be necessary to prevent the spread of such disease, and where the same cannot be properly disinfected. When the Board, upon the written report of the State Veterinarian, or any of his assistants, determine that any animal is affected with, or has been exposed to, any dangerously contagious or infectious disease, the Board, or any member thereof, may agree with the owner upon the value of such animal or property, and in case such agreement cannot be made, said Board, or the member acting in behalf of the Board, may appoint three disinterested citizens of the State to appraise such diseased animal or exposed animals or property. Such appraiser's shall subscribe to an oath in writing to fairly value such animal in accordance with the 
requirements of this act; which oath, together with the valuation fixed by said appraisers, shall be filed with the Board, and be preserved by them. Upon such appraisement being made, it shall become the duty of the owner to immediately destroy such animal and dispose of the same in accordance with the order of said Board, or member thereof, and upon failure so to do, said Board, or member thereof, shall cause such animal or animals or property to be destroyed and disposed of, and thereupon the said owner shall forfeit all right to receive the compensation allowed by said appraisers and provided for by this act. When the Board, upon the written opinion of the State Veterinarian, determines that any barns, stables, out-buildings or premises are so infected that the same cannot be disinfected, they may quarantine such barns, stables, out-buildings or premises from use for the animals that may be infected by such use, and such quarantine shall continue until removed by the Board, and a violation of such quarantine shall be punished as is provided for violations of other quarantine by this act.

"Section 3. The Governor shall appoint a competent veterinary surgeon who shall be known as the State Veterinarian, who, together with his assistants; shall act under the direction of said Board in carrying out the provisions of this act. In the event of the inability of the said State Veterinarian to perform all the work which he may be directed to do by said Board of Commissioners, he may, by and with the advice and consent of said Board, appoint such other necessary assistant veterinarians upon terms not exceeding that paid the State Veterinarian. The State Veterinarian shail receive for his services the sum of $\$ 8$ per day for each day actually employed under the provisions of this act, together with his necessary traveling expenses, to be certified to by said Board of Commissioners.

"Section 4. Whenever said Board of Commissioners shall report to the Governor, that such diseases have become epidemic in certain localities in other States, or that their condition would render such domestic animals liable to convey such diseases, he may, by proclamation, schedule such localities, and prohibit the importation of any live stock of the kind diseased into the State, except under such regulations as may be prescribed by the said Board and approved by the Governor. Any corporation which shall knowingly transport, receive or convey such prohibited stock, shall be deemed guilty of a misdemeanor, and upon conviction thereof, shall be fined not less than $\$ 1,000$ nor more than $\$ 10,000$ for each and every offense, and shall become liable for any and all damage or loss that may be sustained by any party or parties, by reason of such importation or transportation of such prohibited stock. Such penalty shall be recovered 
in any county in this State into, or through which such stock is brought upon information filed in the circuit or county court of any such county or the Superior Court of Cook County. Any person who, knowing that any contagious or infectious disease exists among his domestic animals, shall conceal such fact, or knowing of the existence of such disease, shall sell the animal or animals so diseased, or any exposed animal, or knowing the same, shall remove such diseased or infected animals from his premises to the premises of another, or knowing of the existence of such disease, or exposure, shall drive or lead or ship the same by any car or steamboat to any other place in or out of this State, and any person or persons who shall bring any such diseased, or knowingly, shall bring any such exposed animal or animals into this State from another State; and any person or persons who shall knowingly buy, receive, sell, convey or engage in the traftic of such diseased or exposed stock, and any person who shall violate any quarantine regulations established under the provisions of this act, shall, for each, either, any and all acts above mentioned in this section be guilty of a misdemeanor, and, on conviction thereof, or of any one of said acts, shall be fined in any sum not less than $\$ 25$ nor more than $\$ 200$, and imprisoned in the county jail until the fine and costs are paid, and shall forfeit all right to the compensation for any animal or property destroyed under the provisions of this act. Any veterinary practitioner laving information of any such contagious or infectious disease in this State, and who shall fail to promptly report such knowledge to the Board of Live Stock Commissioner's, shall be fined not exceeding five hundred dollars, or be imprisoned in the county jail not more than one year for each offense.

"Section 5. Whenever said Board shall become satisfied that any dangerously contagious or infectious disease among domestic animals exists throughout any municipality or geographical district within this State, and in their judgment, it is necessary to quarantine such municipality or geographical district in order to prevent the spread of such disease into contiguous territory, they shall report the same to the Governor, who may thereupon by proclamation schedule and quarantine such district, prohibiting all domestic animals of the kind diseased within such district from being moved from one premises to another or over any public highway or any unfenced lot or piece of ground, or from being brought into, or taken from such infected district, except upon obtaining a special permit, signed by the Board of Live Stock Commissioners, or menber thereof, or agent or officer of tre Board duly authorized by it to issue such permits; and such proclamation shall from the time of its publication bind all persons. After the publication of the aforesaid proclamation, it shall be the duty of every person who owns, or is in charge of animals of the 
kind diseased within the scheduled distriet to report to said Board within one week the number and description of such anmals, loca. tion, and the name and address of the owner, and during the coutinuance of such quarantine to report to said Board all cases of sickness, deaths or births among such animals. It shall also be the duty of any and all persous within the scheduled district receiving, and purchasing cattle for slaughter, to delay the killing of such animals until a veterinary surgeon with anthority from said Board is present to make a post-mortem examination of the carcasses. Any violation of the aforesaid quarantine regulations and duties shall be visited with like penalties, which may be recovered in like manner, as is provided for the violation of other quarantine as provided in Section 4, of this Act: Provided, that nothing contained in this section shall be so construed as to prevent the movement of any animals of the kind diseased through such territory under such regulations as the Board of Live Stock Commissioners may prescribe, and the Governor approve: And, provided, firther, that all cattle within the scheduled district slanghtered by order of the Board shall not be taken from said district for slanghter."

"Section 6. Nothing contained in this act, , or any section thereof, shall be interpreted so as to prevent the removal or shipment of diseased or exposed animals, under the orders of the Board created by this act, from one place to another by said Board or its agents, by driving along the public highway or shipment on ears or steamboats, when, in the opinion of said Board such removal is necessary for the suppression of such contagious and infectious disease.

"Section 7. Whenever quarantine is established in accordance with the provisions of Section 2, of this Act, valid notice of the same may be given by leaving with the owner or occupant of any premises iu person, or delivering to any member of his family, or any employe over the age of ten years found on the premises so quarantined, notice thereof, written or printed, or partly written and partly printed, and, at the same time, explaining the contents thereof. Snch quarantine shall be sufficiently proven in any court by the production of a true copy of such notice of quarantine with a return thereon, of the service of the same in the manner above required. Any person violating said quarantine shall be guilty of a misdemeanor and punished as is provided for in Section 4, of this Aet, and, on conviction, shall be liable for all damage that may result to other persons in consequence of such violation: Provided, that any one feeling himself aggrieved by such quarantine may appeal to the full Board of Commissioners, who shall thereupon sustain, modify or annul said quarantine as they 
"Section 8. All fines recovered under the provisions of this act shall be paid into the county treasury of the county in which the suit is tried, by the person collecting the same, in the manner now provided by law, to be used for county purposes; and it shall be the duty of States Attorneys in their respective counties, to prosecute for all violations of this act.

"Section 9. All claims against the State arising from the slaughter of animals, as herein provided for, shall be made to said Board of Commissioners, under such rules and regulations as they may prescribe, and it shall be the duty of said Board of Commissioners to determine the amount which shall be paid in each case on account of animals so slanghtered, which, in cases of animals of the bovine species, shall be based on the fair cash market value thereof for beef, or for use for dairy purposes, not to exceed $\$ 75$ per head; and, in cases of animals of the equine species, on their fair cash market value, not to exceed $\$ 100$ per head, and report the same to the Governor; and the Governor shall endorse thereon his order to the State Auditor, who shall therempon issue his warrant on the State Treasurer for the same.

"Section 10. Said Board of Commissioners, or any member thereof, and the State Veterinarian and his assistants, in the performance of their duties under this act shall have power to call on sheriffs and their deputies, constables and peace officers, mayors of cities, city and town marshals and policemen to assist them in carrying out its provisions, and it is hereby made the duty of all such officers to assist in carrying out the provisions of this act when ordered so to do; and said Commissioners and the State Veterinarian and his assistants, shall have, while engaged in carrying out the provisions of this act, the same powers and protection that other peace officers have, and any such officer who fails or refuses to enforce the lawful orders and quarantine of said Board, or any member thereof, or any veterinarian acting under them, in the proper execution of the powers conferred by this act, shall be deemed guilty of a misdemeanor and punished as provided in Section 4, of this Act.

"Section 11. The said Board shall co-operate with any Commissioner, or other officer, appointed by the United States for the suppression of contagions diseases among domestic animals, so far as the provisions of this act and the appropriations made in accordance therewith will allow, in suppressing and preventing the spread of contagious and infectious diseases among domestic aninials in this State.

"Section 12. It shall be the duty of said Board of Commissioners to keep a record of all their acts and proceedings, and report the 
same to the Governor anmnally, or oftener, if required, for publication. The annual report shall include an itemized statement of all sums expended by them under this act, including a statement of all damages recommended by them to be paid for all animals slaughtered, and the amounts paid therefor.

"Section 13. The members of said Board shall each receive the sum of $\$ 5$ per day for each day necessarily employed in the discharge of their duties, their necessary traveling expenses, and other incidental expenses necessarily incurred in the performance of their duties under this act, to be paid on certified and itemized vouchers to be approved by the Governor.

"Section 14. All acts and parts of acts inconsistent herewith are hereby repealed."

\section{Clause 35 of the General Appropriation Act of 1887.}

Thirty-fifth--For paying damages for animals diseased or exposed to contagion, slanghtered, and for property necessarily destroyed, and for expenses of disinfection of premises, when such disinfection is practicable, under the provisions of any law of this State for the suppression and prevention of the spread of contagious and infectious diseases among domestic animals, the sum of seventy-five thousand dollars $(\$ 75,000)$, per annum, or so much thereof as may be necessary; also, any sums of money that may be received by the Board of Live Stock Commissioners as the net proceeds of the sales of the healthy carcasses of animals slaughtered under the provisions of the law and paid by them into the State Treasury, to be paid only in the manner and on the conditions provided in said law: Provided, that the amount paid for animals slaughtered shall not exceed their actual cash value, and in no case shall the sum paid for any one animal exceed seventy-five dollars (\$75) for cattle, and one hundred.dollars $(\$ 100)$ for animals of the equine species. Also, to the Board of Live Stock Commissioners, the sum of fifteen thousand dollars $(\$ 15,000)$, per arnum, or so much thereof as may be necessary, for the payment of the necessary expenses incurred in the discharge of heir duties as prescribed by law, including the per diem and ext penses of the State and Assistant State Veterinarians, the salary of secretary, and the sum of five dollars (\$5) per day to each member of the Board appointed and acting under the law, approved June 27, 1885 , in force July 1, 1885, for the actual number of days heretofore employed by them in such duties, and for which they have not heretofore received compensation. 


\title{
QUARANTINE REGULATIONS.
}

\author{
PLEURO-PNEUMONIA IN OTHER STATES.
}

On account of the existence of contagious pleuro-pneumonia therein, the Govermor of the State has issued his proclamation forbidding the importation of cattle from the counties of New York, Richmond, Kings and Queens in the State of New York; the counties of Bergen, Passaic, Essex, Union, Hunterdon, Camden, Burlington, Hudson and Middlesex in the State of New Jersey; the comties of Baltimore and Prince George's in the State of Maryland; the counties of Fairfax and Loudoun in the State of Virginia; the county of New Castle in Delaware; the county of Jefferson in West Virginia, and the District of Columbia; except under the following rules and regulations prescribed by this Board and approved by the Governor:

"1. The shipper, or owner of cattle from such infected localities, shall make and present to the proper officer a duly authenticated affidavit that the animal or animals shipped from such infected locality are healthy and free from such disease; that such animal, or animals, have not been in contact with other animals actually infected with such disease, and have not been exposed to such disease in such infected locality; that affiant knows the history of such animal, or animals, for the period of one hundred days before shipment, and that said animal, or animals, have not for said one hundred days been exposed to any infectious disease, and, also, stating where such animals have been kept during the said one hundred days.

"2. Such person shall at the same time, ptesent a duly authenticated certificate from an officer of a court of record where said aftiant resides, that affiant is a responsible person, entitled to credibility and personally kuown to said officer, attested by the seal of his office.

"3. He shall also present a health certificate from a veterinarian acting under State authority, or a reterinary inspector, acting under authority of the United States Burean of Animal Industry, certifying to the present healthy condition of such cattle.

" 4 . All cattle, or other live stock, shipped, or driven, into this State from such infected localities shall be subject to such inspection and examination within this State, or may be held in quarantine with in this State, as may be from time to time thought necessary for public safety by said Live Stock Commission." 
PLEURO-PNEUMONIA IN THIS STATE.

On account of the present existence of contagious pleuro-pneumonia in Cook County, the Governors of the following States and territories have issued proclamations forbidding the importation of cattle from the State of Illinois, except upon compliance with regulations in each proclamation prescribed: States-Connecticut, Colorado, Indiana, Iowa, Kentucky, Kansas, Minnesota, Nebraska, Ohio and Tennessee. Territories-Arizona, Montana and Wyoming. Wisconsin and Michigan only against Cook county.

TEXAS FEVER.

In order to protect the cattle of this State from contracting the disease known as Texas or Splenic Fever, the Governor has issued a proclamation prohibiting the importation of cattle from all that territory of the United States sonth of the thirty-sixth parallel of latitnde west of the Mississippi river, and sonth of the thirty-fifth parallel of latitude east of the Mississippi river, from the first day of April to the first day of November of each year, except under the following regulations prescribed by the Board of Live Stock Commissioners, and approved by the Governor:

First-Cattle from the scheduled localities may, while in transit through this State, be unloaded for the necessary time required in feeding and watering, in regular railroad shipping pens or feed yards.

Second-Cattle may be imported from the scheduled localities where they are destined for immediate slanghter in this State, in which ease such cattle shall not be driven over public highways or commons where cattle are permitted to range at large.

Third-In case persons are desirons of purchasing any of the above prohibited cattle for purposes of feeding and grazing within this State, such persons shall make application to the State Veterinarian, or to this Board, for permission to do so, when such cattle shall be placed in quarantine for a period of ninety days at the owner's expense, under such rules and regulations as shall be prescribed by the Boart. 


\section{PROCLAMATION,}

SCHEDULING A GEOGRAPIICAL DISTRICT IN COOK COUNTY, ILL.

State of Illinois, Executive Department,

Springfield, July 9, 1887.

Whereas, in pursuance of an act of the General Assembly of Illinois, entitled "An Act to amend an Act entitled 'An Act to revise the law in relation to the suppression and prevention of the spread of contagious and infections diseases among domestic animals," approved June 27,1885 , in foree $J$ uly 1,1885 ; approved and in force April 20, 1887, as amended by an Act approved June 15, 1887, in force July 1, 1887, the Board of Live Stock Commissioners of Illinois have reported to me, under date of July 6, 1887, that the disease known as contagions pleuro-pneumonia among cattle now exists throughont the following described geographical district in the State of Illinois, bounded by the following lines, to-wit: Commencing at a point on the west shore of Lake Michigan, where the south side of Twenty-second Street in the City of Chicago, in Cook County, touches said Lake; thence west along the south side of said 'Twenty-second Street, and on a line extended west to the Desplaines River; thence northwardly along the east shore of said river to the south line of the Town of Leyden; thence east to the southwest corner of the Town of Jefferson; thence north along the west line of the said Town of Jefferson to the northwest corner thereof; thence east along the northern line of the Towns of Jefferson and Lake View to Lake Michigan, and thence southerly along the west shore of Lake Michigan to the place of beginning; and

Whereas, said Board of Live Stock Commissioners have, in pursuance of said act, reported to me that in their judgment it is necessary to schedule and quarantine such geographical district in order to prevent the spread of said disease in said district, and into contiguous territory, and have recommended that I schedule and quarantine said district in accordance with the provisions of Sec. 5 , of said act; therefore,

I, Richard J. Oglesby, Governor of the State of Illinois, as prorided by Section 5, of said above entitled act, do hereby make proclamation of the foregoing facts, and schedule the above designated geographical district, and prohibit all domestic animals of the bovine 
species within said district from being moved from one premises to another, or over any public highway or any unfenced lot or piece of ground, or from being brought into, or taken from said district, except upon obtaining a special permit, signed by the Board of Live Stock Commissioners, or member thereof, or agent or officer of the Board, duly anthorized by it to issue such permits.

This proclamation to go into effect from and after its publication.

In Testimony Whereof, I hereto set my hand, and cause the Great Seal of State to be affixed.

(Seal.) Done at the City of Springfield, the day and year first above written.

By the Governor:

R. J. Oglessy.

H. D. Dement, Secretary of State.

Rules Governing the Movement of Cattle turovgh the DisTRict.

1. No restrictions are placed upon the movement of bovine animals by rail when passing through the district.

2. Any bovine animal brought into said district in violation of quarantine regulations prescribed in the Governor's proclamation, shall be treated as an infected animal, and liable to condemnation and slanghter, under the provisions of law and the owner, and the person in charge thereof will be subject to the penalties provided by law.

\author{
John M. Pearson, \\ H. McChesner, \\ E. S. WiLson, \\ Board of Live Stock Commissioners.
}

Approveả:

R. J. Oglesby. 

LIBRARY OF CONGRESS

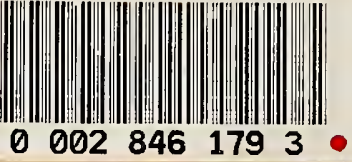

\section{Members OF THE BOARD,}

Jno. M. Pearson, Chairman, Godfrey, Ill.

II. MCChesney, Chicago, (Stock Yards), Ill.

E. S. WILson, Olney, 111 .

C. P. JoIrnson, Secretary, springfield, Ill.

Jonn Casewell, State Veterinarian, 20 South Carpenter Street, Chicago, Ill.

Office of the Board, at Springfield, Ill. 